\title{
Amyloid $\beta$-Protein Dimers Rapidly Form Stable Synaptotoxic Protofibrils
}

\author{
Brian 0'Nuallain, ${ }^{1}$ Darragh B. Freir, ${ }^{1}$ Andrew J. Nicoll, ${ }^{2}$ Emmanuel Risse, ${ }^{2}$ Neil Ferguson, ${ }^{1}$ Caroline E. Herron, ${ }^{1}$ \\ John Collinge, ${ }^{2,3}$ and Dominic M. Walsh ${ }^{1}$ \\ ${ }^{1}$ Laboratory for Neurodegenerative Research, Conway Institute, University College Dublin, Belfield, Dublin 4, Republic of Ireland and ${ }^{2}$ Department of \\ Neurodegenerative Disease and ${ }^{3}$ MRC Prion Unit, UCL Institute of Neurology, London WCN1 3BG, United Kingdom
}

\begin{abstract}
Nonfibrillar, water-soluble low-molecular weight assemblies of the amyloid $\beta$-protein $(\mathrm{A} \beta)$ are believed to play an important role in Alzheimer's disease (AD). Aqueous extracts of human brain contain $\mathrm{A} \beta$ assemblies that migrate on SDS-polyacrylamide gels and elute from size exclusion as dimers $(\sim 8 \mathrm{kDa})$ and can block long-term potentiation and impair memory consolidation in the rat. Such species are detected specifically and sensitively in extracts of Alzheimer brain suggesting that SDS-stable dimers may be the basic building blocks of AD-associated synaptotoxic assemblies. Consequently, understanding the structure and properties of $A \beta$ dimers is of great interest. In the absence of sufficient brain-derived dimer to facilitate biophysical analysis, we generated synthetic dimers designed to mimic the natural species. For this, $A \beta(1-40)$ containing cysteine in place of serine 26 was used to produce disulphide cross-linked dimer, $(\mathrm{A} \beta \mathrm{S} 26 \mathrm{C})_{2}$. Such dimers had no detectable secondary structure, produced an analytical ultracentrifugation profile consistent for an $\sim 8.6$ $\mathrm{kDa}$ protein, and had no effect on hippocampal long-term potentiation (LTP). However, (A $\beta S 26 \mathrm{C})_{2}$ aggregated more rapidly than either $\mathrm{A} \beta$ S26C or wild-type monomers and formed parastable $\beta$-sheet rich, thioflavin T-positive, protofibril-like assemblies. Whereas wildtype $\mathrm{A} \beta$ aggregated to form typical amyloid fibrils, the protofibril-like structures formed by $(\mathrm{A} \beta \mathrm{S} 26 \mathrm{C})_{2}$ persisted for prolonged periods and potently inhibited LTP in mouse hippocampus. These data support the idea that $\mathrm{A} \beta$ dimers may stabilize the formation of fibril intermediates by a process distinct from that available to $\mathrm{A} \beta$ monomer and that higher molecular weight prefibrillar assemblies are the proximate mediators of $A \beta$ toxicity.
\end{abstract}

\section{Introduction}

The amyloid $\beta$-protein $(\mathrm{A} \beta)$ is believed to play a central role in Alzheimer's disease $(\mathrm{AD})$ and like several other proteins associated with neurodegeneration, has the ability to self-associate, and can form an array of different assemblies ranging from dimers all the way to aggregates of fibrils (Powers and Powers, 2008). Initially, it was assumed that $\mathrm{A} \beta$ toxicity was mediated by fibrils similar to those present in amyloid plaques, but recent data suggest that nonfibrillar, water-soluble assemblies of $\mathrm{A} \beta$ may also be important (Klein et al., 2001; Glabe, 2008; Shankar and Walsh, 2009).

Biochemical analysis of brain indicates that the levels of nonfibrillar forms of $\mathrm{A} \beta$ correlate well with synaptic loss and presence of dementia (Lue et al., 1999; McLean et al., 1999; Wang et al., 1999; Tomic et al., 2009; Mc Donald et al., 2010) and that ex vivo such assemblies can impair synaptic form and function (Shankar et al., 2008). Specifically, we have shown that human brain contains $\mathrm{A} \beta$ assemblies that migrate on SDS-polyacrylamide

Received July 8, 2010; revised Aug. 18, 2010; accepted Aug. 27, 2010.

This work was supported by funding to D.M.W. from Science Foundation Ireland (Grant 08/1N.1/B2033), the Health Research Board (Grant RP/2008/30), and the National Institutes of Health (Grant IR01AG027443). We thank Gwen Manning and Dr. Elia Giuliano for assistance with mass spectrometry.

Correspondence should be addressed to Dominic M. Walsh or Brian 0'Nuallain, Laboratory for Neurodegenerative Research, School of Biomolecular and Biomedical Science, Conway Institute, University College Dublin, Belfield, Dublin 4, Republic of Ireland. E-mail: dominic.walsh@ucd.ie or brian.onuallain@ucd.ie.

DOI:10.1523/JNEUROSCI.3537-10.2010

Copyright $\odot 2010$ the authors $\quad 0270-6474 / 10 / 3014411-09 \$ 15.00 / 0$ gels and elute from size exclusion as dimers $(\sim 8 \mathrm{kDa})$, block long-term potentiation (LTP), inhibit synapse remodeling, and impair memory consolidation (Shankar et al., 2008). Such species are detected specifically in extracts of $\mathrm{AD}$ brain suggesting that SDS-stable dimers may be the basic building blocks of ADassociated synaptotoxic $A \beta$ assemblies (Kuo et al., 1996; Roher et al., 1996). The role of low- $n$ oligomers of $A \beta$ in the range of dimer to tetramer is also supported by in vitro studies using peptides bearing design mutations. For instance, substituting glycine for leucine within the GxxxG repeat motif of $A \beta$ indicates that $A \beta$ mediated neurotoxicity is directly linked to the abundance of mass spectrometry-detected dimers and trimers (Hung et al., 2008). Similarly, peptides containing G33A or G29/33A substitutions form low- $n$ oligomers that fail to block LTP (Harmeier et al., 2009). This latter finding indicates that aggregation size alone is not the sole determinant of synaptotoxicity and that structure is also critical. Consequently, establishing the amyloidogenicity and structure of $\mathrm{A} \beta$ dimers in the brain, CSF, and blood of $\mathrm{AD}$ patients are of great diagnostic and therapeutic interest.

In the absence of sufficient brain-derived $A \beta$ dimers, we and others have generated synthetic cross-linked $\mathrm{A} \beta$ dimers to mimic the natural species (Shankar et al., 2008; Kok et al., 2009). In our studies $A \beta(1-40)$ containing cysteine in place of serine 26 was used to produce disulphide cross-linked dimers, (A $\beta S 26 \mathrm{C})_{2}$. Given that such dimer preparations share a similar synaptotoxic profile with natural dimers, we undertook experiments to investigate the biophysical and aggregation properties of $(\mathrm{A} \beta \mathrm{S} 26 \mathrm{C})_{2}$ in 
the hope that this might shed light on processes occurring in $\mathrm{AD}$ brain. Here we report that $(\mathrm{A} \beta \mathrm{S} 26 \mathrm{C})_{2}$ aggregated rapidly to form protofibril-like assemblies and that freshly isolated $(\mathrm{A} \beta \mathrm{S} 26 \mathrm{C})_{2}$ did not block LTP whereas $(\mathrm{A} \beta \mathrm{S} 26 \mathrm{C})_{2}$ solutions that were allowed to form protofibrils did. These data support the idea that $\mathrm{A} \beta$ dimers may stabilize the formation of fibril intermediates by a process distinct from that available to $A \beta$ monomer and that such intermediates are potent synaptotoxins.

\section{Materials and Methods}

Peptides, chemicals, and reagents. Wild-type human A $\beta 1-40$, DAEFRHDSGYEVHHQKLVFFAEDVGSNKGAIIGLMVGGVV, and A $\beta 1-40$ in which serine 26 was substituted with cysteine (A $\beta S 26 \mathrm{C})$ were purchased from the Keck Biotechnology Center (Yale University, New Haven, CT). Peptide mass and purity were determined by electrospray ionization/ion trap mass spectrometry and reverse-phase HPLC, respectively. All peptides had the correct mass and were $>95 \%$ pure.

All chemicals were obtained from Sigma-Aldrich, and unless indicated otherwise were of the highest purity available. Unbranched dextran standards of molecular masses 43,800; 21,400; 9890, and 4440 were purchased from Pharmacosmos. Water was double-distilled and deionized using a Milli-Q system (Millipore).

Disulfide cross-linking of A $\beta S 26 C$. Peptide was solubilized at $\sim 0.18$ $\mathrm{mg} / \mathrm{ml}$ in milliQ water, diluted 1:1 with $20 \mathrm{~mm}$ ammonium bicarbonate, $\mathrm{pH} 8.2$, to generate a $\sim 20 \mu \mathrm{M}$ (with respect to monomer) peptide solution and bubbled with oxygen for $\sim 5-10 \mathrm{~min}$. Solutions were incubated at room temperature for $5 \mathrm{~d}$ and each day bubbled with oxygen. To facilitate disassembly of aggregates formed during the oxidation reaction, the peptide solution was lyophilized and subsequently incubated in 50 mм Tris- $\mathrm{HCl}, \mathrm{pH} 8.0$, containing $5 \mathrm{M}$ guanidine $\mathrm{HCl}$, for $\sim 4 \mathrm{~h}$ before size exclusion chromatography (SEC).

SEC isolation of peptide conformers. The oxidized A $\beta S 26 \mathrm{C}$ was subjected to SEC on a preparative HiLoad 16/60 Superdex 75 column (GE Healthcare) eluted with $25 \mathrm{~mm}$ ammonium acetate, $\mathrm{pH} 8.5$, at a flow rate of $0.6 \mathrm{ml} / \mathrm{min}$ using an AKTA FPLC system (GE Healthcare). Samples were centrifuged at room temperature and $16,000 \times g$ for $20 \mathrm{~min}$ and 2.0 $\mathrm{ml}$ of supernatant injected onto the column. Peptides were detected by absorbance at $280 \mathrm{~nm}$ and $1.2 \mathrm{ml}$ fractions collected. To minimize peptide aggregation, fractions were immediately put on ice, and if necessary, diluted with eluent so that the peptide content was $\leq 0.15 \mathrm{mg} / \mathrm{ml}$. Peptide concentration was determined by absorbance at $275 \mathrm{~nm}$ using the molar extinction coefficient for tyrosine $\left(\varepsilon_{275}=1400 \mathrm{M}^{-1} \mathrm{~cm}^{-1}\right)$. Fractions that contained highly pure $(\mathrm{A} \beta S 26 \mathrm{C})_{2}$ or A $\beta$ S26C monomer were used immediately for biophysical and/or aggregation studies. Wild-type $\mathrm{A} \beta$ was solubilized in $0.1 \%$ ammonium hydroxide to produce a $\sim 0.2 \mathrm{mg} / \mathrm{ml}$ solution and monomer isolated by SEC as described for A $\beta$ S26C. Conformer purity was confirmed by SDS-PAGE and matrix-assisted laser ionization time-of-flight mass spectrometry (MALDI-ToF MS) (Hu et al., 2008).

SDS-PAGE. Samples from peptide cross-linking reactions and aggregation experiments were electrophoresed on $16 \%$ polyacrylamide SDStris-tricine gels in the presence or absence of $50 \mathrm{~mm} \beta$-mercaptoethanol and visualized by silver staining (Shevchenko et al., 1996).

Peptide aggregation. Assembly of monomeric and dimeric A $\beta$ into higher-ordered aggregates was investigated in quiescent and agitated reactions ( 5 replicates for each sample time point) using a thioflavin $\mathrm{T}$ (ThT) binding assay adapted for use in microtiter plates (Betts et al., 2008). The concentration of peptide in SEC-isolated $(\mathrm{A} \beta S 26 \mathrm{C})_{2}$ and monomer fractions was determined by measuring absorbance at $275 \mathrm{~nm}$ and peptides then diluted to $0.15 \mathrm{mg} / \mathrm{ml}$ with $25 \mathrm{~mm}$ ammonium acetate, $\mathrm{pH}$ 8.5. Such solutions were further diluted with $45 \mathrm{~mm}$ sodium phosphate, $\mathrm{pH} 7.4$, to produce stock solutions of $0.087 \mathrm{mg} / \mathrm{ml}$ in $20 \mathrm{~mm}$ sodium phosphate, $\mathrm{pH}$ 7.4. These solutions were subsequently serially diluted 2-30-fold into assay buffer (20 mm sodium phosphate, $\mathrm{pH} 7.4$ ) to final concentrations of $0.0029-0.044 \mathrm{mg} / \mathrm{ml}$ and $100 \mu \mathrm{l}$ of each added to wells of a 96-well polystyrene microtiter plate (ThermoFisher Scientific). Five microliters of $2 \mathrm{~mm}$ ThT in MillQ water was added into appropriate wells, including controls that did not contain peptide. For time course
SEC, electron microscopy (EM), or light scattering analyses, samples were incubated without ThT. Instead, the reaction progress for such samples was determined by monitoring the ThT signal of replicate samples that contained the dye. Quiescent peptide aggregation was initiated by incubating the plate at $37^{\circ} \mathrm{C}$, and agitated samples were shaken at 700 rpm and $37^{\circ} \mathrm{C}$ in a VorTemp 56 incubator/shaker (Labnet International). Each reaction was monitored in real-time by ThT fluorescence $\left(\mathrm{Ex}_{435 \mathrm{~nm}}\right.$ and $\mathrm{Em}_{485 \mathrm{~nm}}$ ) using a SpectraMax M2 multidetection microplate reader (Molecular Devices Corp.) (Betts et al., 2008). Prior studies have shown that the continuous presence of ThT did not affect reaction kinetics (Betts et al., 2008).

Sedimentation velocity analytical ultracentrifugation. Experiments were performed on a Beckman XLI analytical ultracentrifuge fitted with an An50-Ti rotor in quartz cells containing two-sector centerpieces. Samples of freshly SEC-isolated (A $\beta S 26 \mathrm{C})_{2}$ were centrifuged at 50,000 rpm and $20^{\circ} \mathrm{C}$ and absorbance data were collected at 230 and $278 \mathrm{~nm}$ over $20 \mathrm{~h}$, with scans recorded every $10 \mathrm{~min}$. Sedimentation velocity data were analyzed using the $\mathrm{c}(\mathrm{s})$ distribution method in the software SEDFIT (v11.8) (Schuck et al., 2002). For the analyses, partial specific volume $(\bar{v})$ for $(\mathrm{A} \beta \mathrm{S} 26 \mathrm{C})_{2}$ was calculated from the amino acid sequence using the software SEDNTERP (Laue et al., 1992).

Light scattering. The molar masses for $(\mathrm{A} \beta \mathrm{S} 26 \mathrm{C})_{2}$ aggregates was determined by multi-angle laser light scattering (MALLS). One milliliter of a $3 \mathrm{~d}$ incubated $15 \mu \mathrm{M}(\mathrm{A} \beta S 26 \mathrm{C})_{2}$ was loaded onto a Superdex 75 10/300 GL column (GE Healthcare) equilibrated in $20 \mathrm{~mm}$ sodium phosphate, pH 7.4, and eluted using a Prominence HPLC instrument (Shimdazu Europa $\mathrm{GmbH}$ ) daisy-chained with a Dawn HeleosII MALLS detector and Optilab dRX refractometer (Wyatt Technology Corp.). The column was maintained at $20^{\circ} \mathrm{C}\left( \pm 0.1^{\circ} \mathrm{C}\right)$ using an oven (Wyatt Technology Corp.) and the delay volumes between instruments and band-broadening were determined by injecting a $1 \mathrm{mg} / \mathrm{ml}$ BSA solution through the system. Molar masses were calculated from the intensity of scattered light at 18 different angles, as a function of protein concentration and SEC elution volume. The intrinsic instrumental baseline for each data channel was subtracted and the molar mass across a given 2D slice of the elution profile determined using the ASTRA V HPLC software (Wyatt Technology Corp.). To ensure robust data fitting, the apparent molar mass for the elution peak was determined as a function of the width of fitted windows for the front end, center, and trailing edge of the peak.

Circular dichroism spectroscopy. A $\beta$ solutions were placed in a $1 \mathrm{~mm}$ path length quartz cuvette (Starna Scientific Ltd.) and spectra obtained at $22^{\circ} \mathrm{C}$ using a J-810 Jasco spectropolarimeter. Spectra were generated from three data accumulations between $\sim 195-260 \mathrm{~nm}$ with $10 \mathrm{~nm} / \mathrm{min}$ continuous scanning and a $0.5 \mathrm{~nm}$ bandwidth. To minimize any artifactual circular dichroism (CD) signal by aggregate-induced light scattering, samples from aggregation studies were centrifuged at $16,000 \times g$ for 20 min at room temperature. Raw data were manipulated by subtraction of buffer spectra and by binomial smoothing according to the manufacturer's instructions (Jasco) and data displayed as molar ellipticity $(\theta)$.

Electron microscopy. Negative contrast EM was performed as described previously (Walsh et al., 1997). Aliquots $(10 \mu \mathrm{l})$ of peptide sample were applied to carbon-coated Formvar grids (Electron Microscopy Sciences), cross-linked with $0.5 \%(\mathrm{v} / \mathrm{v})$ glutaraldehyde, stained with $2 \%(\mathrm{w} / \mathrm{v})$ uranyl acetate solution (Ted Pella) and examined using a Tecnai $\mathrm{G}^{2}$ Spirit BioTWIN electron microscope (FEI).

In vitro electrophysiology. Six- to eight-week-old male C57BL/6 mice were anesthetized with isoflurane $/ \mathrm{O}_{2}$ and decapitated. Brains were rapidly removed and immersed in ice-cold sucrose-based artificial CSF (ACSF) that contained (in mM): 75 sucrose, $87 \mathrm{NaCl}, 2.5 \mathrm{KCl}, 25 \mathrm{NaHCO}_{3}, 25$ glucose, $1.25 \mathrm{NaH}_{2} \mathrm{PO}_{4}, 0.5 \mathrm{CaCl}_{2}, 7 \mathrm{MgCl}_{2}$. Parasagittal sections $(350 \mu \mathrm{m})$ were prepared using a vibratome VT1000S (Leica) and slices allowed to recover for at least $90 \mathrm{~min}$ in normal ACSF [ $\mathrm{nACSF}$ contained (in mM): 119 $\mathrm{NaCl}, 2.5 \mathrm{KCl}, 1.3 \mathrm{MgSO}_{4}, 2.5 \mathrm{CaCl}_{2}, 26.2 \mathrm{NaHCO}_{3}, 11$ D-glucose, 1 $\mathrm{NaH}_{2} \mathrm{PO}_{4}$ ) in a BSC-PC submerged incubation chamber (Warner Instruments). Thereafter, slices were continuously perfused with oxygenated nACSF at a rate of $2-3 \mathrm{ml} / \mathrm{min}$ at $30^{\circ} \mathrm{C}$. A stainless steel microelectrode (FHC Inc.) was used to stimulate the hippocampal Schaffer collateral pathway, and extracellular EPSPs (fEPSPs) were recorded in the stratum radiatum of the CA1 region using glass microelectrodes $(2-4$ 
A

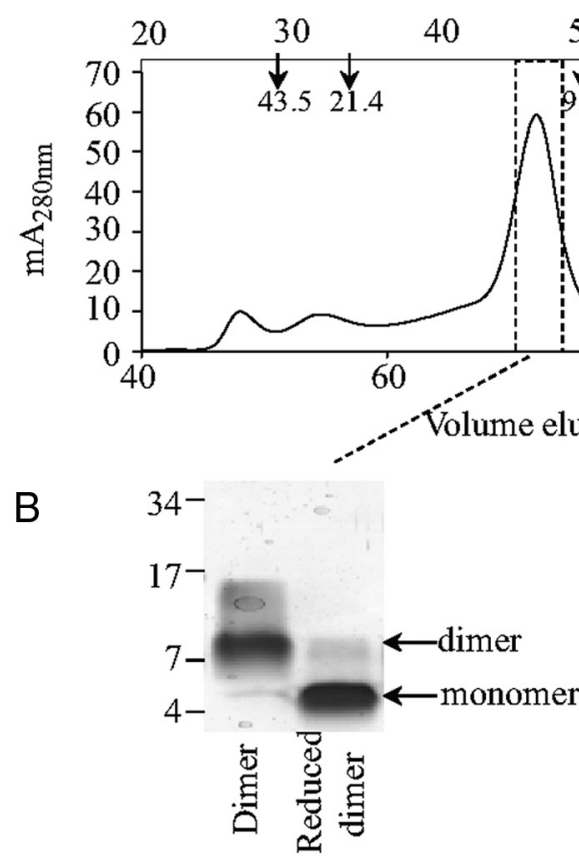

Fraction \#
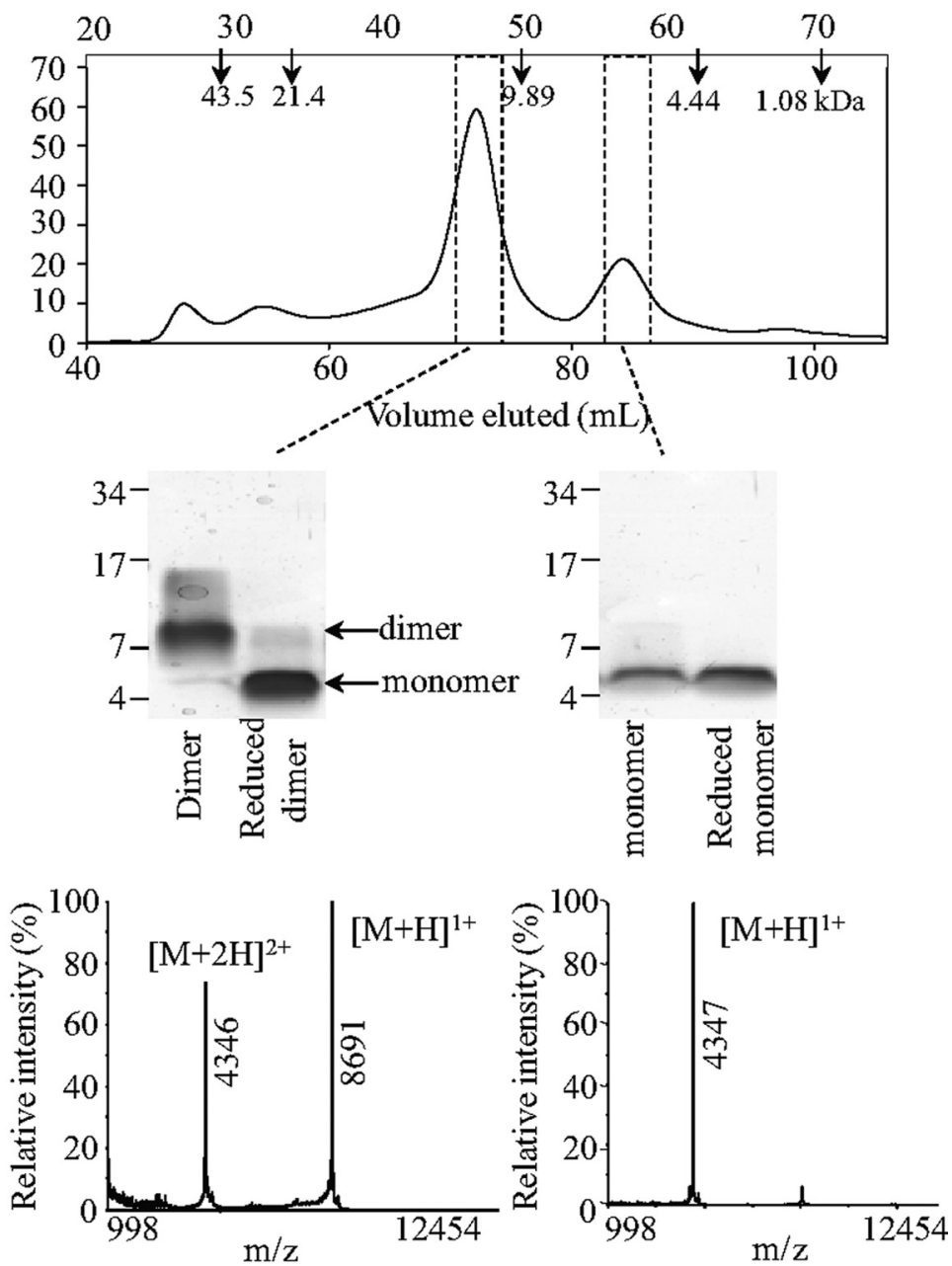

C
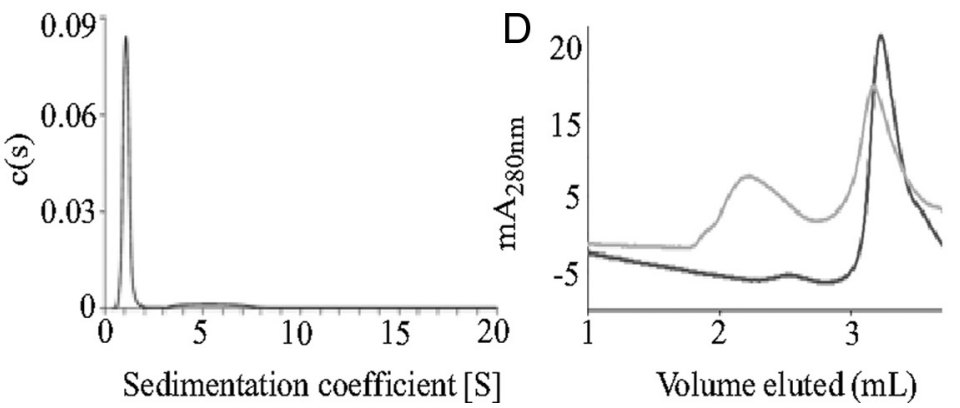

Figure 1. Isolation and initial characterization of $A \beta S 26 C$ dimers. Disulfide cross-linked $A \beta$ dimers were generated by atmospheric oxidation of $20 \mu \mathrm{m} \mathrm{A} \beta S 26 \mathrm{C}$ in $10 \mathrm{~mm}$ sodium bicarbonate, $\mathrm{pH} 8.5$, for $5 \mathrm{~d}$ at room temperature. $\boldsymbol{A}$, The cross-linked $A \beta$ dimer product was isolated by SEC using a HiLoad 16/60 Superdex 75 column equilibrated with 25 mm ammonium acetate, pH 8.5 . Arrows indicate elution of dextran standards. B, SDS-PAGE and MALDI-ToF MS analysis of the two low molecular weight major SEC peaks confirms the presence of a disulfide cross-link in the dimer but not monomer fractions. $\boldsymbol{C}$, Analytical ultracentrifugation analysis confirmed the predominant species to have a predicted mass of $10 \pm 2 \mathrm{kDa}$. $\boldsymbol{D}$, The same dimer used for AUC was incubated at room temperature for $16 \mathrm{~h}$ and when rechromatographed on SEC revealed a significant peak in the void volume (gray line) that was not detected in the $t=0$ sample (black line).

tizer (Molecular Devices). Data were recorded using a pClamp10 (Molecular Devices) and later analyzed using Clampfit.10 software (Molecular Devices).

In all experiments, fresh or aggregated $(\mathrm{A} \beta \mathrm{S} 26 \mathrm{C})_{2}$, or buffer was added to the perfusate after a stable baseline period and circulated in the bath for the remainder of the experiment. Immediately before use, the $3 \mathrm{~d}$ aggregated material was spun at $16,000 \times g$ for 20 min at room temperature and the supernatant added to the perfusate. LTP was induced 30 min after introduction of peptide or vehicle and recorded for at least $60 \mathrm{~min}$ post-tetanus.

General curve fitting. Data points from aggregation time courses were fitted using SigmaPlot 2000, version 6 (Systat Software).

\section{Results \\ Highly pure A $\beta S 26 C$ dimers are isolated using preparative SEC}

The oxidized A $\beta$ S26C peptide produced four major elution peaks $(\sim 48, \sim 55$, $\sim 72$, and $\sim 84 \mathrm{ml}$ ) when chromatographed on a preparative HiLoad 16/60 Superdex 75 (GE Healthcare) column (Fig. 1A). Calibration of size exclusion columns using globular protein standards does not allow accurate assessment of $\mathrm{A} \beta$ monomer size (Walsh et al., 1997), whereas the use of dextran standards does (Päiviö et al., 2004; Walsh et al., 2005). Based on the use of unbranched dextran standards the apparent molecular weight of $\mathrm{A} \beta \mathrm{S} 26 \mathrm{C}$ conformers in the two largest peaks $(\sim 72$ and $\sim 84 \mathrm{ml})$ were $\sim 10$ (dimer) and $\sim 5.7$ (monomer) $\mathrm{kDa}$, respectively (Fig. $1 A$ ). SDS-PAGE and mass spectroscopy analyses confirmed that these fractions contained (A $\beta S 26 \mathrm{C})_{2}$ and monomeric $\mathrm{A} \beta$ (Fig. $1 A, B)$. The minor SDS-PAGE bands in the $(\mathrm{A} \beta \mathrm{S} 26 \mathrm{C})_{2}$ fractions that migrated $>9 \mathrm{kDa}$ were transiently and artificially induced by SDS (Wahlström et al., 2008). Reducing agent completely dissociated (A $\beta S 26 \mathrm{C})_{2}$ to monomer, indicating that dimers were indeed stabilized by an intermolecular disulfide bond (Fig. 1B). Furthermore, analytical ultracentrifugation (AUC) sedimentation velocity studies demonstrated that the dominant peptide conformer had an apparent molecular weight of $\sim 10 \pm 2$ $\mathrm{kDa}$ (Fig. 1C). However, trace quantities of higher ordered assemblies of $\sim 95 \mathrm{kDa}$ were also observed. Given that the AUC experiment took $\sim 20 \mathrm{~h}$ to complete it seems likely that these higher molecular weight

$\mathrm{M} \Omega$ ) filled with nACSF. Test stimuli were delivered once every $30 \mathrm{~s}$ $(0.033 \mathrm{~Hz})$ and the stimulus intensity was adjusted to produce a baseline fEPSP of $30-40 \%$ of the maximal response. A stable baseline was recorded for at least $20 \mathrm{~min}$ before addition of fresh or aggregated $(\mathrm{A} \beta \mathrm{S} 26 \mathrm{C})_{2}$. LTP was induced by theta-burst stimulation (TBS, 4 pulses delivered at $100 \mathrm{~Hz}, 10$ times, with an interburst interval of $200 \mathrm{~ms}$ ) delivered at baseline intensity. Field potentials were recorded with an Axon CNS Muticlamp 700B amplifier coupled to a Digidata 1440A digi- species formed during the experiment. In accord with this observation rechromatographing of the sample incubated for $16 \mathrm{~h}$ at room temperature revealed the appearance of species eluting in the void volume (Fig. $1 D$ ). These finding suggest that the $(\mathrm{A} \beta S 26 \mathrm{C})_{2}$ has a high propensity for aggregation and prompted us to compare the aggregation of $(\mathrm{A} \beta \mathrm{S} 26 \mathrm{C})_{2}$ versus $\mathrm{A} \beta$ monomer. 


\section{Dimeric A $\beta$ S26C forms stable protofibrils}

We have previously demonstrated that $(\mathrm{A} \beta \mathrm{S} 26 \mathrm{C})_{2}$ are potent neurotoxins (Hu et al., 2008; Shankar et al., 2008). Thus, we investigated whether $(\mathrm{A} \beta \mathrm{S} 26 \mathrm{C})_{2}$ had a propensity to aggregate and if their toxicity was dependent on aggregation. Freshly isolated $(\mathrm{A} \beta \mathrm{S} 26 \mathrm{C})_{2}$ was diluted as described in the Materials and Methods and aggregation monitored using thioflavin $\mathrm{T}$ (ThT) binding. Under quiescent conditions $(\mathrm{A} \beta \mathrm{S} 26 \mathrm{C})_{2} \quad(5-10 \mu \mathrm{M})$ rapidly formed ThT-positive assemblies without a measurable lag time (Fig. $2 A, E$ ), but unlike typical amyloid fibrils the $(\mathrm{A} \beta \mathrm{S} 26 \mathrm{C})_{2}$ aggregates did not readily sediment when centrifuged $(16,000 \times g$ for $20 \mathrm{~min}$ ) (Fig. $2 B)$. Moreover, CD studies indicated that the $(\mathrm{A} \beta \mathrm{S} 26 \mathrm{C})_{2}$ aggregates contained significant $\beta$-structure (Fig. $2 D$ ), whereas freshly isolated $(\mathrm{A} \beta \mathrm{S} 26 \mathrm{C})_{2}$, and A $\beta$ S26C and wild-type monomers incubated for $1 \mathrm{~d}$ had little secondary structure (Fig. $2 C, D)$. As previously documented, the secondary structure of SEC-isolated wildtype monomer changed slowly (Walsh et al., 1999) and A $\beta S 26 C$ monomer appeared to change even more slowly (Fig. $2 D)$. Dimer aggregation was critically dependent on peptide concentration with no discernible ThT binding evident at $(\mathrm{A} \beta \mathrm{S} 26 \mathrm{C})_{2}$ concentrations $\leq 2.5 \mu \mathrm{M}$ in samples incubated at $37^{\circ} \mathrm{C}$ for $44 \mathrm{~h}$ (Fig. $2 E)$. The progress curves for $(\mathrm{A} \beta S 26 \mathrm{C})_{2}$ aggregation fitted to single exponential linear plots $\left(R^{2}=0.96 \pm 0.04\right)$ producing an apparent rate constant of $0.085 \pm 0.03$ $\mathrm{h}^{-1}$ (Fig. $2 \mathrm{~F}$ ).

Having demonstrated that $(\mathrm{A} \beta \mathrm{S} 26 \mathrm{C})_{2}$ shows an unusually high propensity for aggregation, we investigated the morphology and size distribution of the aggregates formed. SEC analysis of $(\mathrm{A} \beta \mathrm{S} 26 \mathrm{C})_{2}$ aggregate species in reactions sampled over a $3 \mathrm{~d}$ period indicated that these assemblies eluted in the void volume of the Superdex 75 10/300 GL column (Fig. 3A). The SEC-isolated aggregates were not sedimented by centrifugation and had $\sim 4$-fold greater ThT signal than the same weight of SEC-isolated $(\mathrm{A} \beta \mathrm{S} 26 \mathrm{C})_{2}$ or freshly prepared monomers, and $\sim 2$-fold lower than for $\mathrm{A} \beta$ wild-type fibrils (Fig. $3 B, C$ ). Consistent with $\mathrm{CD}$ analysis of unfractionated $(\mathrm{A} \beta \mathrm{S} 26 \mathrm{C})_{2}$ aggregates, the SECisolated aggregates were rich in $\beta$-sheet structure whereas the $(\mathrm{A} \beta \mathrm{S} 26 \mathrm{C})_{2}$ fraction had no detectable secondary structure (Fig. $3 D)$. SEC-MALLS indicated that the apex of the $(\mathrm{A} \beta S 26 \mathrm{C})_{2}$ aggregate peak contained assemblies with a molecular weight distribution of $\sim 1-2 \mathrm{MDa}$, with a leading shoulder containing species $\geq 2 \mathrm{MDa}$ (Fig. $3 E$ ). The distribution of species detected are consistent with $\mathrm{A} \beta$ assemblies that contained $\sim 100-450$ $(\mathrm{A} \beta \mathrm{S} 26 \mathrm{C})_{2}$ molecules. These aggregates had morphologies highly similar to A $\beta$ protofibrils (Harper et al., 1997; Walsh et al., 1997) appearing as short flexible rods with an average width of $5.8 \pm 0.2$ observed signal versus time.
B
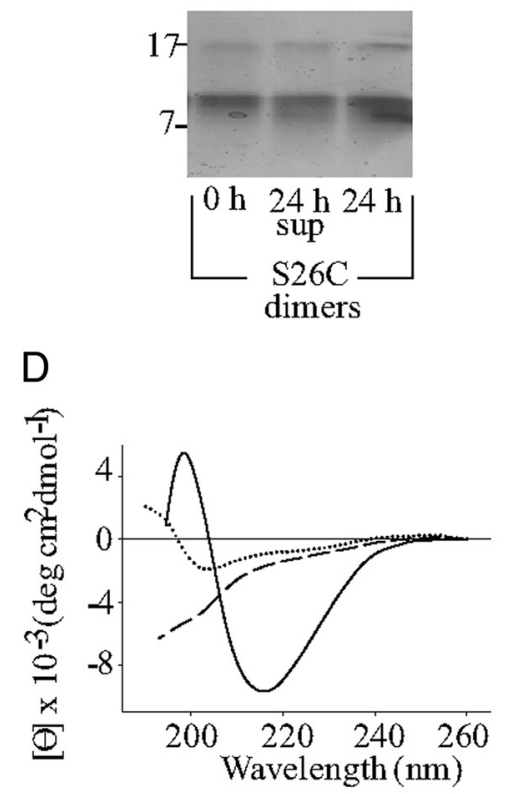

$\mathrm{F}$

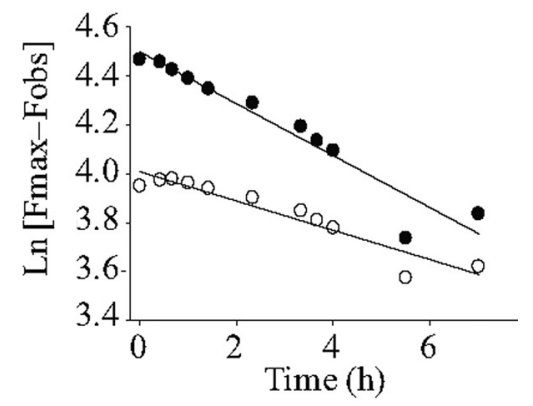

Figure 2. Quiescent aggregation of A $\beta S 26 C$ dimers. A, Progress curves for the formation of ThT-positive material are shown as 政 mM sodium phosphate, pH 7.4, plus $10 \mu \mathrm{M}$ ThT. $\boldsymbol{B}$, Freshly isolated and $1 \mathrm{~d}$ aggregated dimer samples were analyzed by ( Dimer supernatant (sup) was generated by centrifuging the sample at $16,000 \times g$ for 20 min at room temperature. $C_{,}$ D, Circular dichroism spectra for solutions of freshly isolated $(\mathrm{A} \beta \mathrm{S} 26 \mathrm{C}))_{2}(10 \mu \mathrm{M},-), \mathrm{S} 26 \mathrm{C}(20 \mu \mathrm{M},--)$ or wild-type $(20 \mu \mathrm{M}, \cdots)$, momers at $0 \mathrm{~h}(\boldsymbol{C})$ and after $24 \mathrm{~h}$ at $37^{\circ} \mathrm{C}(\boldsymbol{D})$. $\boldsymbol{E}$, Concentration dependency of $S 26 \mathrm{C}$ dimer aggregation: $10 \mu \mathrm{m}(\boldsymbol{O}) ; 5 \mu \mathrm{M}$ kinetics. The data from $\boldsymbol{E}$ were plotted as the natural $\log$ of the difference between the maximum ThT fluorescence and the

$\mathrm{nm}(n=9)$ (Fig. 4$)$. The protofibrils grew in length from $59 \pm 12$ $\mathrm{nm}(n=7)$ after $1 \mathrm{~d}$ to $139 \pm 35 \mathrm{~nm}(n=7)$ after 3 d incubation. Importantly these assemblies were relatively stable since protofibrils in certain samples persisted even after a 1-month-long incubation at $37^{\circ} \mathrm{C}$. However, the length of protofibrils appeared to increase with time, with the $30 \mathrm{~d}$ incubated sample containing protofibrils twice as long, $284 \pm 59 \mathrm{~nm}(n=7)$, as the protofibrils detected at $3 \mathrm{~d}$ (Fig. 4). The largest protofibrils in the aged samples pelleted after centrifugation at $16,000 \times g$ for $20 \mathrm{~min}$, leaving $\sim 40 \%$ of the ThT-positive material in solution which by EM contained shorter protofibrils, $181 \pm 31 \mathrm{~nm}(n=7)$ (Fig. $4 D, E)$.

To investigate the formation and stability of protofibrils over more tractable time scales we studied aggregation of $(\mathrm{A} \beta \mathrm{S} 26 \mathrm{C})_{2}$, $\mathrm{A} \beta \mathrm{S} 26 \mathrm{C}$ and wild-type monomers under conditions where the samples were vigorously agitated. In contrast to quiescent conditions, agitation initiated aggregation of all peptides within a cou- 
A
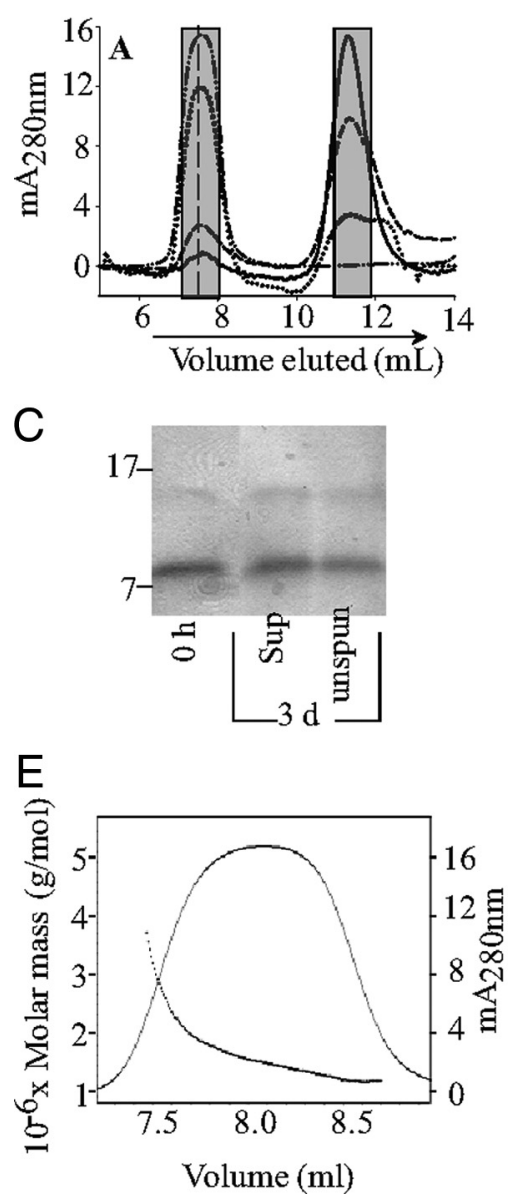

B
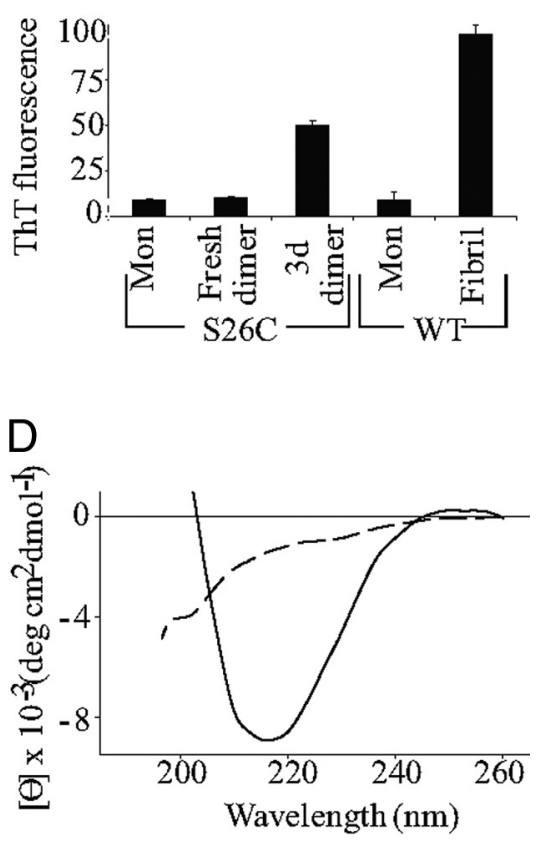

whereas $(\mathrm{A} \beta \mathrm{S} 26 \mathrm{C})_{2}$ aggregated even at $1.25 \mu \mathrm{M}$ (supplemental Fig. $1 A, B$, available at www.jneurosci.org as supplemental material). Consistent with quiescent experiments, $20 \mu \mathrm{M}(\mathrm{A} \beta \mathrm{S} 26 \mathrm{C})_{2}$ formed aggregates in agitated samples without a lag (supplemental Fig. $1 C$, available at www.jneurosci.org as supplemental material), were not pelleted by centrifugation (supplemental Figs. 1, 2, available at www. jneurosci.org as supplemental material) and had protofibril-like morphology. The average lengths and widths of protofibrils formed in agitated samples $(78 \pm 22 \mathrm{~nm}$, $n=8$ and $6.0 \pm 1.0 \mathrm{~nm}, n=8$, respectively) were highly similar to those of protofibrils formed under quiescent conditions (compare Fig. $4 C$ and supplemental Fig. $2 B$, available at www.jneurosci.org as supplemental material). In contrast, the products for the $\mathrm{A} \beta \mathrm{S} 26 \mathrm{C}$ and wild-type monomer reactions readily pelleted and had typical amyloid fibril morphology when examined by EM. Interlaced networks of fibrils with diameters ranging from 7 to $11 \mathrm{~nm}$ and up to several micrometers in length were detected in incubates of both S26C and wild-type monomers (supplemental Fig. 2, available at www.jneurosci.org as supplemental material).

\section{Aggregated, but not fresh A $\beta$ S26C dimers inhibit synaptic plasticity}

We have previously shown that A $\beta S 26 C$ dimers can potently block LTP both in vivo (Hu et al., 2008) and in vitro (Shankar et al., 2008). In those studies $(\mathrm{A} \beta \mathrm{S} 26 \mathrm{C})_{2}$ was isolated by SEC, frozen at $-80^{\circ} \mathrm{C}$ and shipped on dry ice to our collaborators, where the samples were stored frozen, then thawed and used for electrophysiology experiments. However, given the findings presented above regarding the high propensity for dimer to form aggre$\mathrm{pH} 7.4$, without agitation and at intervals samples removed and chromatographed on a Superdex $7510 / 300 \mathrm{GL}$ column equilibrated with $20 \mathrm{~mm}$ sodium phosphate, $\mathrm{pH}$ 7.4. The chromatographs show the conversion of $A \beta$ dimers into high molecular weight conformers that eluted in the void volume (dashed vertical line). Freshly prepared $\mathrm{A} \beta$ dimers after $4 \mathrm{~h}$ at $4^{\circ} \mathrm{C}(-)$, and $\mathrm{A} \beta$ dimer preparation after $6 \mathrm{~h}(--), 24 \mathrm{~h}(\cdot \cdot)$, and $3 \mathrm{~d}(-\cdot \cdot)$ at $37^{\circ} \mathrm{C}$. The gray bars show the peak fractions that were collected for subsequent experiments. $\boldsymbol{B}$, ThT fluorescence of $\mathrm{SEC}$-isolated $3 \mathrm{~d}$ aggregated $(\mathrm{A} \beta \mathrm{S} 26 \mathrm{C})_{2}$ compared with the same concentration $(0.09 \mathrm{mg} / \mathrm{ml})$ of the unaggregated peptide and WT A $\beta$ conformers. C, SDS-PAGE analysis of time 0 and 3 dincubated dimer before (unspun) and after centrifugation (sup). D, Circular dichroism spectra obtained using SEC isolated dimers ( $2.5 \mu \mathrm{M},--)$ and the void component of SEC fractionated $3 \mathrm{~d}$ aggregated dimers $(3 \mu \mathrm{M},-)$. $\boldsymbol{E}$, Multi-angle light scattering indicated that the void component of SEC fractionated $3 \mathrm{~d}$ aggregated dimers $(-)$ had a size distribution of $\sim 1-4 \mathrm{MDa}(\cdots)$.

ple of hours (compare Fig. $2 A$ and supplemental Fig. $1 A-C$, available at www.jneurosci.org as supplemental material). The concentration of $(\mathrm{A} \beta \mathrm{S} 26 \mathrm{C})_{2}$ required to facilitate aggregation was reduced almost fourfold when samples were agitated, with fully formed ThT-positive assemblies evident within $\sim 4 \mathrm{~h}$ at $(\mathrm{A} \beta \mathrm{S} 26 \mathrm{C})_{2}$ concentration as low as $1.25 \mu \mathrm{M}$ (supplemental Fig. $1 A$, available at www.jneurosci.org as supplemental material). In contrast, without shaking no ThT-positive aggregates were formed in $(\mathrm{A} \beta \mathrm{S} 26 \mathrm{C})_{2}$ solution $<5 \mu \mathrm{M}$ (Fig. $2 E$ ). The progress curves for the agitated $(\mathrm{A} \beta \mathrm{S} 26 \mathrm{C})_{2}$ reactions were sigmoidal with short lag phases, $t_{\mathrm{lag}}<1 \mathrm{~h}$. The absence of a measurable lag phase for the quiescent $(A \beta S 26 C)_{2}$ reactions is somewhat puzzling but presumably reflects the significantly larger peptide concentrations used in the quiescent reactions. The maximum ThT signal amplitude for (A $\beta S 26 \mathrm{C})_{2}$ aggregation was proportionate to the amount of peptide used (supplemental Fig. $1 \mathrm{~A}$, available at www. jneurosci.org as supplemental material). Wild-type monomer was considerably less amyloidogenic than $(\mathrm{A} \beta \mathrm{S} 26 \mathrm{C})_{2}$ since it only formed ThT-positive aggregates at concentration $\geq 5 \mu \mathrm{M}$, gates we set out to determine whether the previously documented plasticity-impairing activity of S26C derived from authentic dimers or aggregates of $(\mathrm{A} \beta \mathrm{S} 26 \mathrm{C})_{2}$. First we used analytical ultracentrifugation and SEC to assess aggregation in samples that had been frozen and thawed versus samples that had been freshly isolated and immediately used for AUC. When freshly isolated $(\mathrm{A} \beta \mathrm{S} 26 \mathrm{C})_{2}$ was immediately rechromatographed it produced a single peak, whereas when the same solution was frozen and stored at $-80^{\circ} \mathrm{C}$ for 1 week and then rechromatographed a small second high molecular weight peak was detected (supplemental Fig. 3, available at www.jneurosci.org as supplemental material). Next we performed experiments in which $(\mathrm{A} \beta \mathrm{S} 26 \mathrm{C})_{2}$ was isolated and used for electrophysiology experiments within $4 \mathrm{~h}$ (between 1 and $4 \mathrm{~h}$ ) of collection (Fig. 5C,D). Hippocampal slices perfused with vehicle produced robust LTP measuring $160 \pm$ $8 \%$, at 1 h post-TBS $(n=7)$, while slices perfused with $50 \mathrm{nM}$ freshly isolated $(\mathrm{A} \beta \mathrm{S} 26 \mathrm{C})_{2}$ produced a highly similar potentiation $(155 \pm 8 \%, n=7)$. The concentration of $(\mathrm{A} \beta S 26 \mathrm{C})_{2}$ used here is significantly higher than the minimal concentration 

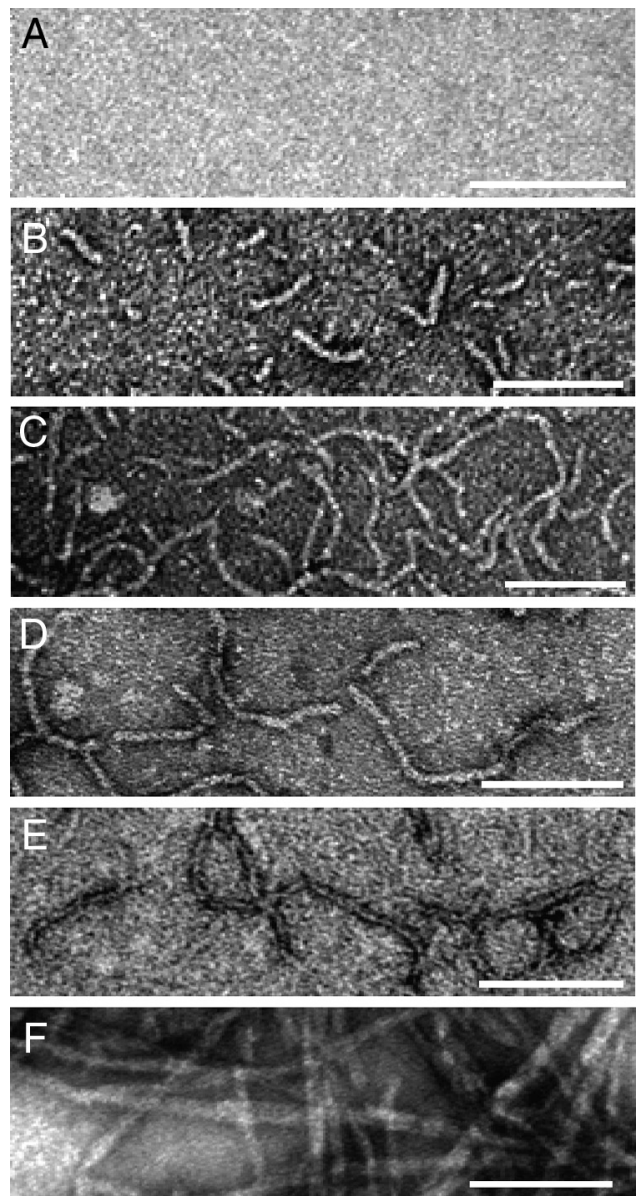

Figure 4. Morphology of aggregates formed by $A \beta S 26 C$ dimers. $A-E$, Negative contrast $E M$ was performed on freshly isolated $10 \mu \mathrm{m}(\mathrm{A} \beta \mathrm{SS} 26 \mathrm{C})_{2}$ in $25 \mathrm{~mm}$ ammonium acetate, $\mathrm{pH} 8.5$ (A), and on aliquots of the $(\mathrm{A} \beta \mathrm{S} 26 \mathrm{C})$, reaction after incubation at $37^{\circ} \mathrm{C}$ in $20 \mathrm{~mm}$ sodium phosphate, $\mathrm{pH} 7.4$, for $1 \mathrm{~d}(\boldsymbol{B}), 3 \mathrm{~d}(\boldsymbol{C})$, or 1 month (D). When the 1 month sample was centrifuged at $16,000 \times g$ and room temperature for $20 \mathrm{~min}$ and the supernatant examined protofibrils were still detected $(\boldsymbol{E})$, but on average these protofibrils were shorter than those detected in the unspun sample. $\boldsymbol{F}$, Fibrils formed from $30 \mu \mathrm{m}$ monomeric wild-type $A \beta$ after a 2 week incubation. Images are representative of at least $6-8$ fields from duplicate grids for each time point. Scale bar, $100 \mathrm{~nm}$.

of $(\mathrm{A} \beta \mathrm{S} 26 \mathrm{C})_{2}$ previously shown to impair hippocampal LTP (Shankar et al., 2008) and strongly suggests that the previously documented impairment of plasticity was not mediated by authentic $(\mathrm{A} \beta \mathrm{S} 26 \mathrm{C})_{2}$. Given the demonstration that $(\mathrm{A} \beta \mathrm{S} 26 \mathrm{C})_{2}$ can aggregate when frozen (supplemental Fig. 3, available at www. jneurosci.org as supplemental material), we set out to determine whether deliberately aggregated $(\mathrm{A} \beta \mathrm{S} 26 \mathrm{C})_{2}$ could block LTP. When the same $(A \beta S 26 C)_{2}$ solution that had been tested when fresh and failed to block LTP was aggregated for $3 \mathrm{~d}$ it completely inhibited LTP (103 $\pm 10 \%, n=7)$ (Fig. 5C,D). Moreover, EM examination of the $3 \mathrm{~d}$ aggregated material demonstrated the presence of abundant protofibrils (Fig. $5 B$ ) indistinguishable to those observed in prior aggregation experiments (Fig. 4). Thus together these results indicate that $\mathrm{S} 26 \mathrm{C}$ dimers rapidly assemble into relatively stable protofibrils that can block LTP.

\section{Discussion}

Burgeoning evidence suggests that nonfibrillar water-soluble forms of $A \beta$ are the principal mediators of neurotoxicity in $A D$, but, as yet the precise conformation and assembly form(s) of A $\beta$ responsible remain unidentified (Klein et al., 2001; Hardy and
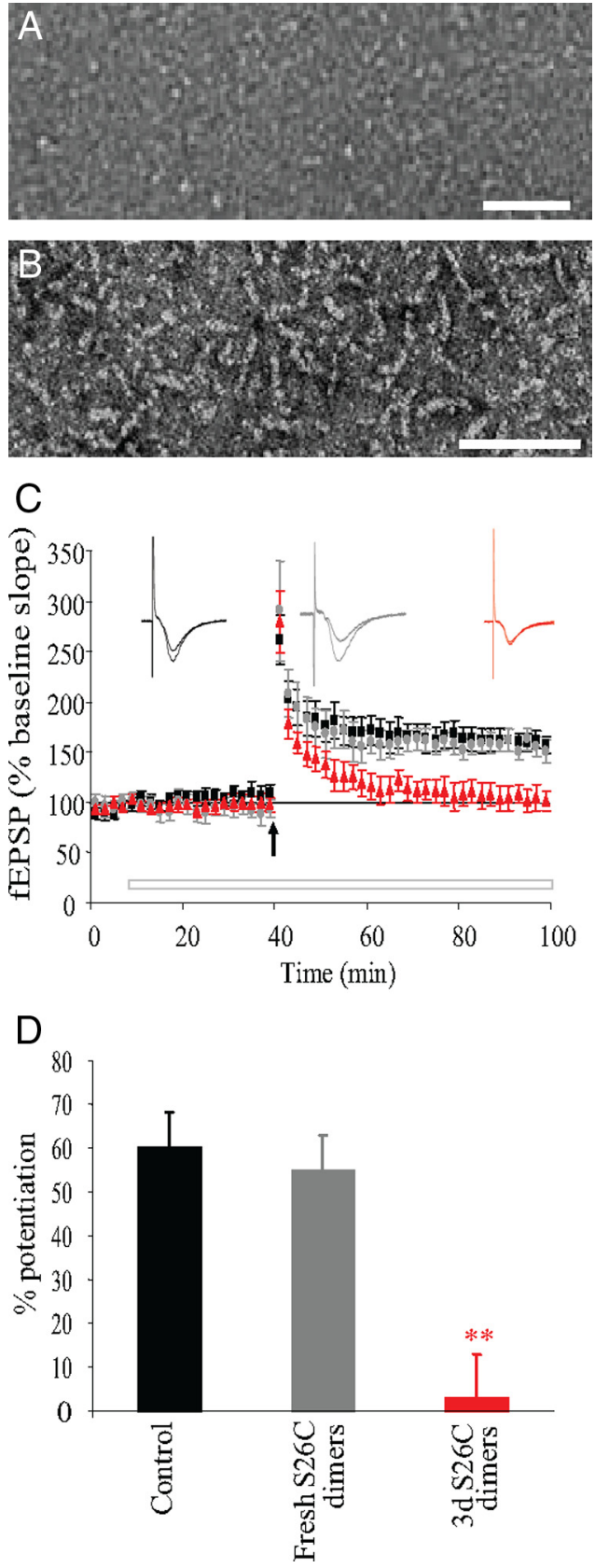

Figure 5. Protofibrils formed from A $\beta S 26 C$ dimers potently inhibit LTP. A-C, Freshly SECisolated (A $\beta S 26 \mathrm{C})_{2}$ was immediately diluted to $17 \mu \mathrm{m}$ with $25 \mathrm{~mm}$ ammonium acetate, $\mathrm{pH} 8.5$, and used to prepare samples for negative contrast electron microscopy $(\boldsymbol{A})$. As in the prior figure, micrographs are representative of at least $6-8$ fields from duplicate grids for each time point. Size bar $=100 \mathrm{~nm}$. The remaining solution was held on ice for $1-4 \mathrm{~h}$, then diluted to $10 \mu \mathrm{m}$

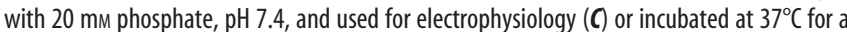
further $72 \mathrm{~h}(\boldsymbol{B})$. C, Perfusion of mouse hippocampal slices with nACSF containing $3 \mathrm{~d}$ aggregated (A $\beta S 26 C)_{2}$ (red triangles), but not vehicle (ammonium acetate/phosphate buffer) (black squares) or an equivalent amount ( $50 \mathrm{~nm}$ ) of freshly isolated (A $\beta S 26 \mathrm{C})_{2}$ (gray circles) blocked $\operatorname{LTP}(p<0.001)$. Values are mean \pm SEM percentage of baseline, $n=7$ (aggregated dimer), $n=7$ (fresh dimer) and $n=7$ (vehicle). The horizontal bar represents the time during which the vehicle or peptide was present in the recording solution. Insets show typical fEPSP 5 min pre- and post-TBS. Calibration: $5 \mathrm{~ms}, 0.5 \mathrm{mV}$. D, The histogram shows the magnitude of LTP between 55 and 60 min post-TBS for all 3 groups; ${ }^{*} p<0.01$ (ANOVA).

Selkoe, 2002; Klein et al., 2004). Recent work has indicated that SDS-stable $\mathrm{A} \beta$ dimers present in the water-soluble phase of human brain are strongly associated with AD-type dementia (Mc Donald et al., 2010) and possess disease-relevant toxic activity 


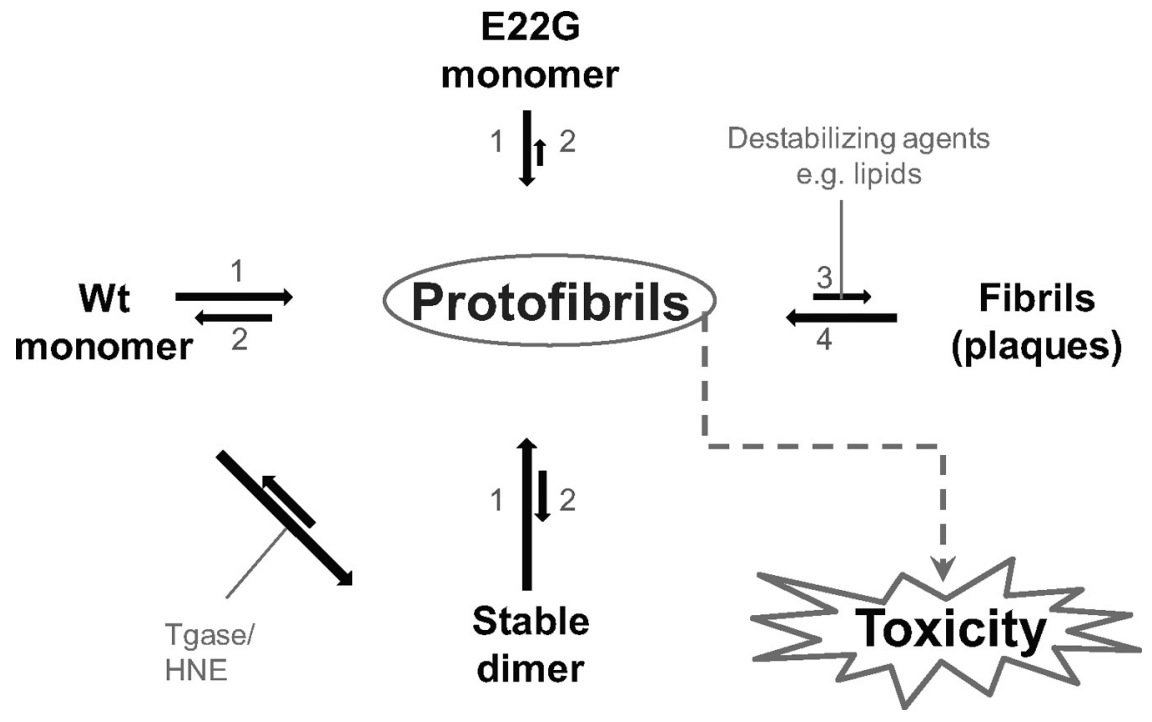

Figure 6. A model for dimer-mediated protofibril toxicity. In vitro, wild-type $A \beta$ monomer is known to assemble into amyloid fibrils by a process that appears to require the transient formation of prefibrillar structures referred to as protofibrils. The steadystate level of protofibrils is controlled by four key reactions: (1) formation of protofibrils, (2) disassembly of protofibrils (3), formation of fibrils and (4) disassembly of fibrils. The rate of protofibril formation and the time period over which protofibrils persist is strongly influenced by $A \beta$ primary sequence. Specifically, the population of protofibrils is greater for $A \beta 1-42$ and $A \beta 1-40 E 22 G$ than for wild-type $A \beta 1-40$ (Walsh et al., 1997; Nilsberth et al., 2001). Similarly, covalent cross-linking of $A \beta$ by either 4-hydroxynonenal (HNE) or transglutaminase (TGase) accelerates formation of protofibrils while inhibiting fibril formation (Siegel et al., 2007; Hartley et al., 2008). Here we demonstrate that pure (A $3526 C)_{2}$ also increases the rate of protofibril, but not fibril formation. This suggests that formation of a stable dimer (either covalently cross-linked as shown in the current study or noncovalently cross-linked as seen in human brain) may better facilitate protofibril formation and persistence than $A \beta$ monomer. It has also been demonstrated that certain lipids can destabilize mature fibrils and liberate protofibrils (Johansson et al., 2007; Martins et al., 2008) and that such "reverse" protofibrils, like "forward" protofibrils are potent synaptotoxins (Martins et al., 2008). Since SDS-stable $A \beta$ dimers appear specific for $A D$ it seems plausible that the presence of dimers and abundance of protofibrils are linked. That is, dimers exert toxicity as a consequence of their ability to form relatively stable protofibrils.

(Shankar et al., 2008). However, due to the lack of highly pure brain-derived $\mathrm{A} \beta$ it has not been possible to study the conformation and aggregation kinetics of this material. Thus we have chosen to study synthetic dimers which mimic the toxic activity of the natural SDS-stable dimer (Hu et al., 2008; Shankar et al., 2008). Unlike prior work with covalently linked $A \beta$ which used crude mixtures containing both cross-linked and uncross-linked species (Siegel et al., 2007; Hartley et al., 2008; Moore et al., 2009), and which lacked definition regarding aggregation state and the sites of cross-linking, we used highly pure $A \beta$ dimer with a defined linkage site. Specifically, dimers were formed by the substitution of serine 26 with cysteine and subsequent disulphide bond formation and isolated free of other assemblies by SEC.

Like the wild-type monomer, (A $\beta S 26 \mathrm{C})_{2}$ was devoid of discernible secondary structure and exhibited little or no binding to thioflavin T. De novo fibrillogenesis from $\mathrm{A} \beta$ monomer is believed to involve a series of conformational alterations that include the formation of thermodynamically unstable amyloidogenic intermediates, self-association and stabilization, and finally, protofibril association into mature fibrils (Harper and Lansbury, 1997; O'Nuallain and Wetzel, 2002; Glabe, 2008; Roychaudhuri et al., 2009). In contrast, $(\mathrm{A} \beta \mathrm{S} 26 \mathrm{C})_{2}$ aggregation proceeded rapidly with the formation of stable protofibril-like assemblies which persisted for relatively long periods. In agreement with prior reports, protofibrils appeared as a continuum of structures which by EM ranged in size from imperfect spheres of $5 \mathrm{~nm}$ diameter to flexible rods up to $200 \mathrm{~nm}$ long and $\sim 5-6 \mathrm{~nm}$ wide (Harper et al., 1997, 1999; Walsh et al., 1997; Johansson et al., 2006) and included structures sometimes referred to as $\mathrm{A} \beta$-derived diffusible ligands (ADDLs)
(Lambert et al., 1998; Hepler et al., 2006). This increase in the propensity to form protofibrils coupled with a reduced tendency to form mature fibrils suggests that there may be some subtle microstructural differences between the monomer and $(\mathrm{A} \beta \mathrm{S} 26 \mathrm{C})_{2}$ which act to change the rate constant for protofibril formation, and/or reduce the rate constant for conversion of protofibrils into fibrils (Fig. 6). Conformational changes in the mid-region of $\mathrm{A} \beta$ are thought to be required for the transition of protofibrils into fibrils (Williams et al., 2005; Kheterpal et al., 2006) and cross-linking at residue 26 may act to suppress this transition.

But how does this translate to $A \beta$ in the human brain? For instance, to make dimers is it necessary to start from monomeric $\mathrm{A} \beta$, and if it is, how then is it possible that monomers can contribute to two different pathways? First, there is evidence that dimerized APP may undergo amyloidogenic processing (Munter et al., 2007) thus providing a route for the direct production of discrete $A \beta$ dimer subunits. Once formed such dimers may associate with other dimers in a pathway distinct from the aqueous-phase assembly of individual monomers. Second, other factors that preferentially stabilize dimer formation from monomers would be predicted to enable assembly by a pathway similar to that we have observed for $(\mathrm{A} \beta \mathrm{S} 26 \mathrm{C})_{2}$, whereas conditions that do not favor dimer formation would lead to lower levels of protofibril. It is noteworthy that protofibril formation and stability are modulated by factors that may also facilitate dimer formation and stabilization. Specifically, covalent cross-linking of $\mathrm{A} \beta$ by either 4-hydroxynonenal (HNE) or transglutaminase (TGase) or the presence of certain small molecules accelerate formation of protofibrils while inhibiting fibril formation (Williams et al., 2005; Siegel et al., 2007; Hartley et al., 2008; Moore et al., 2009). Although it has not yet been demonstrated that transglutaminase catalyzed isopeptide $\varepsilon$-(c-glutamyl)lysine bond formation leads exclusively to formation of cross-linked dimer, the data available suggest that intermolecular bond formation between lysine 16 and glutamine 15 is the only likely site of linkage (Ikura et al., 1993). Thus the enhancement in the rate of protofibril formation and persistence observed in prior crosslinking studies is probably attributable to the presence of dimer which aggregates in a manner distinct from monomer. The rate of protofibril formation and the time period over which protofibrils persist are strongly influenced by $A \beta$ primary sequence (Lashuel et al., 2003; Päiviö et al., 2004). For example, the population of protofibrils is greater for $A \beta 1-42$ and $A \beta 1-40 E 22 G$ than for wild-type A $\beta 1-40$ (Walsh et al., 1997; Nilsberth et al., 2001), and it is interesting to speculate that this may reflect an increased tendency of $\mathrm{A} \beta 1-42$ and $\mathrm{A} \beta 1-40 \mathrm{E} 22 \mathrm{G}$ to form dimers.

Moreover, since SDS-stable $\mathrm{A} \beta$ dimers appear specific for $\mathrm{AD}$ it seems plausible that the presence of dimers and abundance of protofibrils are linked. That is, dimers may exert toxicity as a consequence of their ability to form relatively stable protofibrils (Fig. 6). 
In prior studies we have demonstrated that SDS-stable $\mathrm{A} \beta$ dimers from human brain and CSF can impair disease-relevant measures of learning and memory (Klyubin et al., 2008; Shankar et al., 2008) and that synthetic (A $\beta$ S26C $)_{2}$ exhibited a similar activity. Here we have now shown that freshly prepared (A $\beta S 26 \mathrm{C})_{2}$ does not inhibit LTP as such, but rather aggregated dimers in the form of protofibrils mediate this activity. As discussed above this finding is consistent with the previously documented protofibril-mediated inhibition of LTP (Hartley et al., 2008) and with recent observations that $\mathrm{A} \beta$ protofibril levels correlate with spatial learning impairment of AD transgenic mice (Lord et al., 2009). Together our findings suggest that the activity previously ascribed to SDSstable $\mathrm{A} \beta$ dimers, may not reside in dimers per se, but rather in the higher order assemblies they rapidly form. Of course other factors which increase the kinetic stability of protofibrils by a dimerindependent mechanism could also lead to an increase in synaptotoxicity, but given the link between SDS-stable dimers and $\mathrm{AD}$, a dimer-dependent mechanism seems most likely. Similarly, the pathogenicity of assemblies other than protofibrils cannot be discounted and merits further investigation. Moving forward it will also be important to investigate the assembly and toxicity of heterodimers of $\mathrm{A} \beta 1-40 \mathrm{~S} 26 \mathrm{C}$ and $\mathrm{A} \beta 1-42 \mathrm{~S} 26 \mathrm{C}$ and of homodimers of $A \beta 1-42$ and to assess the toxicity of protofibril subpopulations. The latter is particularly important since one might expect that different structures may have different activity. Nonetheless, therapeutic targeting of $\mathrm{A} \beta$ dimers remains attractive since such a strategy should prevent formation of a substantial population of prefibrillar toxic assemblies.

\section{References}

Betts V, Leissring MA, Dolios G, Wang R, Selkoe DJ, Walsh DM (2008) Aggregation and catabolism of disease-associated intra-Abeta mutations: reduced proteolysis of AbetaA21G by neprilysin. Neurobiol Dis 31:442-450.

Glabe CG (2008) Structural classification of toxic amyloid oligomers. J Biol Chem 283:29639-29643.

Hardy J, Selkoe DJ (2002) The amyloid hypothesis of Alzheimer's disease: progress and problems on the road to therapeutics. Science 297:353-356.

Harmeier A, Wozny C, Rost BR, Munter LM, Hua H, Georgiev O, Beyermann M, Hildebrand PW, Weise C, Schaffner W, Schmitz D, Multhaup G (2009) Role of amyloid-beta glycine 33 in oligomerization, toxicity, and neuronal plasticity. J Neurosci 29:7582-7590.

Harper JD, Lansbury PT Jr (1997) Models of amyloid seeding in Alzheimer's disease and scrapie: mechanistic truths and physiological consequences of the time-dependent solubility of amyloid proteins. Annu Rev Biochem 66:385-407.

Harper JD, Wong SS, Lieber CM, Lansbury PT (1997) Observation of metastable Abeta amyloid protofibrils by atomic force microscopy. Chemistry and Biology 4:119-125.

Harper JD, Wong SS, Lieber CM, Lansbury PT Jr (1999) Assembly of A beta amyloid protofibrils: an in vitro model for a possible early event in Alzheimer's disease. Biochemistry 38:8972-8980.

Hartley DM, Zhao C, Speier AC, Woodard GA, Li S, Li Z, Walz T (2008) Transglutaminase induces protofibril-like amyloid beta-protein assemblies that are protease-resistant and inhibit long-term potentiation. J Biol Chem 283:16790-16800.

Hepler RW, Grimm KM, Nahas DD, Breese R, Dodson EC, Acton P, Keller PM, Yeager M, Wang H, Shughrue P, Kinney G, Joyce JG (2006) Solution state characterization of amyloid beta-derived diffusible ligands. Biochemistry 45:15157-15167.

Hu NW, Smith IM, Walsh DM, Rowan MJ (2008) Soluble amyloid-beta peptides potently disrupt hippocampal synaptic plasticity in the absence of cerebrovascular dysfunction in vivo. Brain 131:2414-2424.

Hung LW, Ciccotosto GD, Giannakis E, Tew DJ, Perez K, Masters CL, Cappai R, Wade JD, Barnham KJ (2008) Amyloid-beta peptide (Abeta) neurotoxicity is modulated by the rate of peptide aggregation: Abeta dimers and trimers correlate with neurotoxicity. J Neurosci 28:11950-11958.

Ikura K, Takahata K, Sasaki R (1993) Cross-linking of a synthetic partial- length (1-28) peptide of the Alzheimer beta/A4 amyloid protein by transglutaminase. FEBS Lett 326:109-111.

Johansson AS, Berglind-Dehlin F, Karlsson G, Edwards K, Gellerfors P, Lannfelt L (2006) Physiochemical characterization of the Alzheimer's disease-related peptides A beta 1-42Arctic and A beta 1-42wt. FEBS J 273:2618-2630.

Johansson AS, Garlind A, Berglind-Dehlin F, Karlsson G, Edwards K, Gellerfors P, Ekholm-Pettersson F, Palmblad J, Lannfelt L (2007) Docosahexaenoic acid stabilizes soluble amyloid-beta protofibrils and sustains amyloid-betainduced neurotoxicity in vitro. FEBS J 274:990-1000.

Kheterpal I, Chen M, Cook KD, Wetzel R (2006) Structural differences in Abeta amyloid protofibrils and fibrils mapped by hydrogen exchangemass spectrometry with on-line proteolytic fragmentation. J Mol Biol 361:785-795.

Klein WL, Krafft GA, Finch CE (2001) Targeting small Abeta oligomers: the solution to an Alzheimer's disease conundrum? Trends Neurosci 24:219-224.

Klein WL, Stine WB Jr, Teplow DB (2004) Small assemblies of unmodified amyloid beta-protein are the proximate neurotoxin in Alzheimer's disease. Neurobiol Aging 25:569-580.

Klyubin I, Betts V, Welzel AT, Blennow K, Zetterberg H, Wallin A, Lemere CA, Cullen WK, Peng Y, Wisniewski T, Selkoe DJ, Anwyl R, Walsh DM, Rowan MJ (2008) Amyloid beta protein dimer-containing human CSF disrupts synaptic plasticity: prevention by systemic passive immunization. J Neurosci 28:4231-4237.

Kok WM, Scanlon DB, Karas JA, Miles LA, Tew DJ, Parker MW, Barnham KJ, Hutton CA (2009) Solid-phase synthesis of homodimeric peptides: preparation of covalently-linked dimers of amyloid beta peptide. Chem Commun (Camb) 41:6228-6230.

Kuo YM, Emmerling MR, Vigo-Pelfrey C, Kasunic TC, Kirkpatrick JB, Murdoch GH, Ball MJ, Roher AE (1996) Water-soluble Abeta (N-40, N-42) oligomers in normal and Alzheimer disease brains. J Biol Chem 271:4077-4081.

Lambert MP, Barlow AK, Chromy BA, Edwards C, Freed R, Liosatos M, Morgan TE, Rozovsky I, Trommer B, Viola KL, Wals P, Zhang C, Finch CE, Krafft GA, Klein WL (1998) Diffusible, nonfibrillar ligands derived from Abeta 1-42 are potent central nervous system neurotoxins. Proc Natl Acad Sci U S A 95:6448-6453.

Lashuel HA, Hartley DM, Petre BM, Wall JS, Simon MN, Walz T, Lansbury PT Jr (2003) Mixtures of wild-type and a pathogenic (E22G) form of Abeta40 in vitro accumulate protofibrils, including amyloid pores. J Mol Biol 332:795-808.

Laue T, Shah B, Ridgeway T, Pelletier S (1992) Computer-aided interpretation of analytical sedimentation data for proteins. In: Analytical ultracentrifugation in biochemistry and polymer science (Harding S, Horton J, Rowe A, eds), pp 90-125. Cambridge, UK: Royal Society of Chemistry.

Lord A, Englund H, Söderberg L, Tucker S, Clausen F, Hillered L, Gordon M, Morgan D, Lannfelt L, Pettersson FE, Nilsson LN (2009) Amyloid-beta protofibril levels correlate with spatial learning in Arctic Alzheimer's disease transgenic mice. FEBS J 276:995-1006.

Lue LF, Kuo YM, Roher AE, Brachova L, Shen Y, Sue L, Beach T, Kurth JH, Rydel RE, Rogers J (1999) Soluble amyloid beta peptide concentration as a predictor of synaptic change in Alzheimer's disease. Am J Pathol 155:853-862.

Martins IC, Kuperstein I, Wilkinson H, Maes E, Vanbrabant M, Jonckheere W, Van Gelder P, Hartmann D, D’Hooge R, De Strooper B, Schymkowitz J, Rousseau F (2008) Lipids revert inert Abeta amyloid fibrils to neurotoxic protofibrils that affect learning in mice. EMBO J 27:224-233.

Mc Donald JM, Savva GM, Brayne C, Welzel AT, Forster G, Shankar GM, Selkoe DJ, Ince PG, Walsh DM (2010) The presence of sodium dodecyl sulphate-stable Abeta dimers is strongly associated with Alzheimer-type dementia. Brain 133:1328-1341.

McLean CA, Cherny RA, Fraser FW, Fuller SJ, Smith MJ, Beyreuther K, Bush AI, Masters CL (1999) Soluble pool of Abeta amyloid as a determinant of severity of neurodegeneration in Alzheimer's disease. Ann Neurol 46:860-866.

Moore BD, Rangachari V, Tay WM, Milkovic NM, Rosenberry TL (2009) Biophysical analyses of synthetic amyloid-beta(1-42) aggregates before and after covalent cross-linking. Implications for deducing the structure of endogenous amyloid-beta oligomers. Biochemistry 48:11796-11806.

Munter LM, Voigt P, Harmeier A, Kaden D, Gottschalk KE, Weise C, Pipkorn R, Schaefer M, Langosch D, Multhaup G (2007) GxxxG motifs within 
the amyloid precursor protein transmembrane sequence are critical for the etiology of Abeta42. EMBO J 26:1702-1712.

Nilsberth C, Westlind-Danielsson A, Eckman CB, Condron MM, Axelman K, Forsell C, Stenh C, Luthman J, Teplow DB, Younkin SG, Näslund J, Lannfelt L (2001) The 'Arctic' APP mutation (E693G) causes Alzheimer's disease by enhanced Abeta protofibril formation. Nat Neurosci 4:887-893.

O'Nuallain B, Wetzel R (2002) Conformational Abs recognizing a generic amyloid fibril epitope. Proc Natl Acad Sci U S A 99:1485-1490.

Päiviö A, Jarvet J, Gräslund A, Lannfelt L, Westlind-Danielsson A (2004) Unique physicochemical profile of beta-amyloid peptide variant Abeta1$40 \mathrm{E} 22 \mathrm{G}$ protofibrils: conceivable neuropathogen in arctic mutant carriers. J Mol Biol 339:145-159.

Powers ET, Powers DL (2008) Mechanisms of protein fibril formation: nucleated polymerization with competing off-pathway aggregation. Biophys J 94:379-391.

Roher AE, Chaney MO, Kuo YM, Webster SD, Stine WB, Haverkamp LJ, Woods AS, Cotter RJ, Tuohy JM, Krafft GA, Bonnell BS, Emmerling MR (1996) Morphology and toxicity of Abeta-(1-42) dimer derived from neuritic and vascular amyloid deposits of Alzheimer's disease. J Biol Chem 271:20631-20635.

Roychaudhuri R, Yang M, Hoshi MM, Teplow DB (2009) Amyloid betaprotein assembly and Alzheimer disease. J Biol Chem 284:4749-4753.

Schuck P, Perugini MA, Gonzales NR, Howlett GJ, Schubert D (2002) Sizedistribution analysis of proteins by analytical ultracentrifugation: strategies and application to model systems. Biophys J 82:1096-1111.

Shankar GM, Walsh DM (2009) Alzheimer's disease: synaptic dysfunction and Abeta. Mol Neurodegener 4:48.

Shankar GM, Li S, Mehta TH, Garcia-Munoz A, Shepardson NE, Smith I, Brett FM, Farrell MA, Rowan MJ, Lemere CA, Regan CM, Walsh DM, Sabatini BL, Selkoe DJ (2008) Amyloid-beta protein dimers isolated di- rectly from Alzheimer's brains impair synaptic plasticity and memory. Nat Med 14:837-842.

Shevchenko A, Wilm M, Vorm O, Mann M (1996) Mass spectrometric sequencing of proteins silver-stained polyacrylamide gels. Anal Chem 68:850-858.

Siegel SJ, Bieschke J, Powers ET, Kelly JW (2007) The oxidative stress metabolite 4-hydroxynonenal promotes Alzheimer protofibril formation. Biochemistry 46:1503-1510.

Tomic JL, Pensalfini A, Head E, Glabe CG (2009) Soluble fibrillar oligomer levels are elevated in Alzheimer's disease brain and correlate with cognitive dysfunction. Neurobiol Dis 35:352-358.

Wahlström A, Hugonin L, Perálvarez-Marín A, Jarvet J, Gräslund A (2008) Secondary structure conversions of Alzheimer's Abeta(1-40) peptide induced by membrane-mimicking detergents. FEBS J 275:5117-5128.

Walsh DM, Lomakin A, Benedek GB, Condron MM, Teplow DB (1997) Amyloid beta-protein fibrillogenesis. Detection of a protofibrillar intermediate. J Biol Chem 272:22364-22372.

Walsh DM, Hartley DM, Kusumoto Y, Fezoui Y, Condron MM, Lomakin A, Benedek GB, Selkoe DJ, Teplow DB (1999) Amyloid beta-protein fibrillogenesis. Structure and biological activity of protofibrillar intermediates. J Biol Chem 274:25945-25952.

Walsh DM, Townsend M, Podlisny MB, Shankar GM, Fadeeva JV, El Agnaf O, Hartley DM, Selkoe DJ (2005) Certain inhibitors of synthetic amyloid beta-peptide (Abeta) fibrillogenesis block oligomerization of natural Abeta and thereby rescue long-term potentiation. J Neurosci 25:2455-2462.

Wang J, Dickson DW, Trojanowski JQ, Lee VM (1999) The levels of soluble versus insoluble brain Abeta distinguish Alzheimer's disease from normal and pathologic aging. Exp Neurol 158:328-337.

Williams AD, Sega M, Chen M, Kheterpal I, Geva M, Berthelier V, Kaleta DT, Cook KD, Wetzel R (2005) Structural properties of Abeta protofibrils stabilized by a small molecule. Proc Natl Acad Sci U S A 102:7115-7120. 